$\frac{\mathrm{DE}}{\mathrm{G}} \stackrel{\substack{\text { DE GRUYTER } \\ \text { OPEN }}}{\text { DOI 10.1515/ethemes-2014-0022 }}$

\title{
THE ROLE OF TRADE MANAGEMENT IN THE PROCESS OF OVERCOMING THE SECRETS OF SUSTAINABLE DEVELOPMENT
}

\author{
Svetlana Sokolov Mladenović \\ University of Niš, Faculty of Economics, Serbia \\ \svetlana.sokolov@eknfak.ni.ac.rs \\ Sreten Ćuzović \\ University of Niš, Faculty of Economics, Serbia \\ $\bowtie$ sreten.cuzovic@eknfak.ni.ac.rs
}

UDC

005:339:

502.131 .1

Review paper

Received:

20.06.2014

Accepted:

10.10.2014

\begin{abstract}
Trade, especially retail, plays an important role in linking producers, consumers, as well as employees and the social community at large. In developed market economies, the trade takes the leading position in marketing channels. In that regard, the trade has a good insight into the changes that occur in the production processes, consumer needs, and demands of the society. Given these changes, trade is heading in the direction of creating a competitive advantage in accordance with the principles of sustainable development, which opens up possibilities for application of this concept in trade. The aim of this paper is to explore the possibilities of implementing the concept of sustainable development in trade and trade management. The starting hypothesis of the work is that the trading companies operate in accordance with the principles of sustainable development. The testing of the hypothesis will be carried out from three angles. The research will start with an analysis of the concept of sustainable development. Second, the subject of a separate analysis in this paper will be the content of the concept of sustainable development in trade and retail, as well as the elements affecting the operational viability of trading companies. In that regard, the subject of the analysis will be the top ten trading companies from the list of 250 largest trading companies in the world and their content of the concept of sustainable development. Bearing in mind the results of the research on the concept of sustainable development in these companies, it can be expected that the trade will base its business philosophy on eco-marketing, with parallel acceptance of eco-management. This means that the companies capable of offering products that do not pollute the environment and that are labeled "eco", "bio", or "natural" will ensure their survival in the market. Third, the subject of the research will be the instruments that the trading companies use to achieve the objectives of sustainable business. All these aspects of the research are designed in a way to realize the defined goal and test the initial hypothesis in the paper.
\end{abstract}

Keywords: trade, sustainable development, trading companies, environmental, economic, social dimension.

\footnotetext{
${ }^{1}$ The paper is part of the research within the Project No. 179081, funded by the Ministry of Education, Science and Technological Development of the Republic of Serbia.
} 


\section{Introduction}

The concept of sustainable development has gained in importance in the last ten to fifteen years, especially as environmental problems are becoming more serious and consumers demanding and focused on eco-products. Numerous factors, such as increased consumer awareness, adoption of new statutory and legal regulations, the development of information and communication technologies and increased media attention, have influenced the increased interest of trading companies in the environment, as well as the economic and social impact of their activities. Practice shows that the leading trading companies play a key role in promoting the concept of sustainable development, particularly because of their role of intermediaries between producers and consumers. At the same time, theoretical and empirical studies suggest that trade has the ability to influence the process of production and consumption patterns, but also to encourage producers to favor the consumer needs putting the concept of sustainability in the foreground. All this has caused many leading trading companies to show willingness to regularly inform the public about the sustainability of their operations, to demonstrate their interest in the environmental protection, employees, and society in general, to promote transparency of their operations, better manage risk, and increase brand value and their market share. The milestone in the development of these activities has emerged with the strategy "Towards Retail Sustainability", adopted by the British Retail Consortium (BRC), which states that the trade sector plays an active role in national and international initiatives on sustainability. In addition, the vision of this institution is the sustainability of the trade sector, which is promoted as a competitive sector that cares about its employees and society as a whole, increases environmental performance, and makes considerate use of natural resources. The very concept of sustainable development is gaining in importance as the world is becoming aware of the harmful consequences of human activities on the future of the planet. Unfortunately, companies are becoming aware of the concept of sustainable development when their reputation is called into question due to business contrary to this concept. Given these facts, the aim of this paper is to point out the significance of the concept of sustainable development in trade. In line with the defined goal of research, the work will test the hypothesis that trading companies base their business on the principles of sustainable development. The second hypothesis to be tested is that the concept of sustainable development has a positive impact on the success of the business of trading companies, based on the specific sample. For this reason, the subject of the analysis will be ten leading companies from the list of 250 largest trading companies in the world, as seen by sales volume, i.e. their activities in implementing the concept of sustainable development. 


\section{Theoretical Aspects of the Concept of Sustainable Development}

Chronologically speaking, the concept of sustainable development can be traced back to the thirteenth century. However, it appeared in the literature dealing with environmental protection in the nineteen-seventies, and since then has continuously attracted the attention of many researchers (Jones, Comfort, Hillier, 2011, p. 257). Defining the concept of sustainable development is the subject of a number of theoretical and empirical research, primarily due to the fact that a large number of researchers have worked on the definition of this phenomenon, which has led to the fact that there are as many definitions as there are researchers who have dealt with this issue.

The most commonly cited definition of sustainable development has been given by the World Commission on Environment and Development (1987, p. 43), based on which it refers to "the development that meets the needs of the present without compromising the ability of future generations to meet their own needs". It can be seen that this definition emphasizes the long-term aspect of the concept of sustainability and the introduction of ethical principles in achieving equality between present and future generations.

The implementation of sustainable development in practice brought the need to approach this concept in a more comprehensive manner. This has led to the development of approaches that observe sustainable development in terms of the realization of social and environmental goals. One of these approaches was developed by researchers Callicott and Mumford (1997, p. 32), according to whom "the sustainable development means meeting human needs without compromising the health of the ecosystem". A similar approach, based on the introduction of the environmental component, can be seen in the Sutton's definition (2004, p. 1), based on which "the sustainable development is the ability to maintain things or qualities that are valued in the physical environment". On the other hand, focus on the social component of sustainable development prevails in the attitudes of researcher Dauncey $(2009$, p. 1), who states that "sustainable development should allow for generations of people to achieve social welfare, a vibrant economy, and a healthy environment, without compromising the needs of future generations to meet these needs in the same way".

This approach to defining the concept of sustainable development has resulted in the distinction between the so-called "weak" and "strong" concept of sustainable development. In this regard, "weak" concept of sustainable development emphasizes the development of renewable resources, seeking replacements for non-renewable resources, efficient use of existing resources and the search for technological solutions that will enable addressing the problems of resource depletion and pollution of the living and working environment (Williams and Millington, 2004, p. 100). On the other hand, the "strong" concept of sustainable development is based on the belief that the 
needs of people need to be revised in the sense that they should consume less and significantly reduce the level of consumption (Fuchs and Lorek, 2004, p. 4).

Starting from the previous interpretation of sustainable development, the following segment of the research will give an overview of the most commonly quoted definitions of sustainable development, as can be seen in Table 1

Table 1: Definitions of the concept of sustainable development

\begin{tabular}{|c|c|}
\hline Author(s) & Definition \\
\hline Constanza and Patern (1995, p. 193) & $\begin{array}{l}\text { "The basic idea of sustainability is simple: a } \\
\text { sustainable system is the one that survives } \\
\text { and persists". }\end{array}$ \\
\hline $\begin{array}{l}\text { United Nations } \quad \text { Environment } \\
\text { Programme Finance Initiative (1997) }\end{array}$ & $\begin{array}{l}\text { "Sustainable development depends on the } \\
\text { positive interaction between economic and } \\
\text { social development and environmental } \\
\text { protection, i.e. the balance of interests of } \\
\text { present and future generations". }\end{array}$ \\
\hline Parris and Kates (2003, p. 581) & $\begin{array}{l}\text { "Sustainable development involves meeting } \\
\text { human needs while reducing hunger and } \\
\text { poverty and preserving the eco-system". }\end{array}$ \\
\hline Ehrenfeld (2005, pp. 24-25) & $\begin{array}{l}\text { "Sustainability provides an opportunity for } \\
\text { all forms of life. For humans, it is the } \\
\text { survival and maintenance, as well as a sense } \\
\text { of dignity... Finally, sustainability requires } \\
\text { responsible, ethical choices everywhere in } \\
\text { daily life". }\end{array}$ \\
\hline $\begin{array}{l}\text { General Assembly of the United } \\
\text { Nations }(2005, \text { p. } 2)\end{array}$ & $\begin{array}{l}\text { "Sustainable development, with its } \\
\text { economic, environmental, and social } \\
\text { component, is a key element of the activities } \\
\text { of the United Nations". }\end{array}$ \\
\hline Lozano $(2008$, p. 8) & $\begin{array}{l}\text { "Sustainable development requires a } \\
\text { holistic, continuous, and interactive } \\
\text { relationship between economic, } \\
\text { environmental, and social aspects, and that } \\
\text { every decision has its implications on all } \\
\text { these aspects in the present and future". }\end{array}$ \\
\hline
\end{tabular}

Numerous and varied definitions of the concept of sustainable development in many elements complement each other. Such orientation has sharpened the scientific thought of the concept of sustainable development. New definitions place emphasis on the economic, environmental, and social determinant of the concept of sustainable development. Contemporary literature has accepted these definitions. However, these debates have not taken the issue of the definition of 
the concept of sustainable development of the agenda. Venn diagram is important in this regard, as it illustrates the concept of sustainability through three overlapping circles.

Figure 1: Venn diagram of sustainability

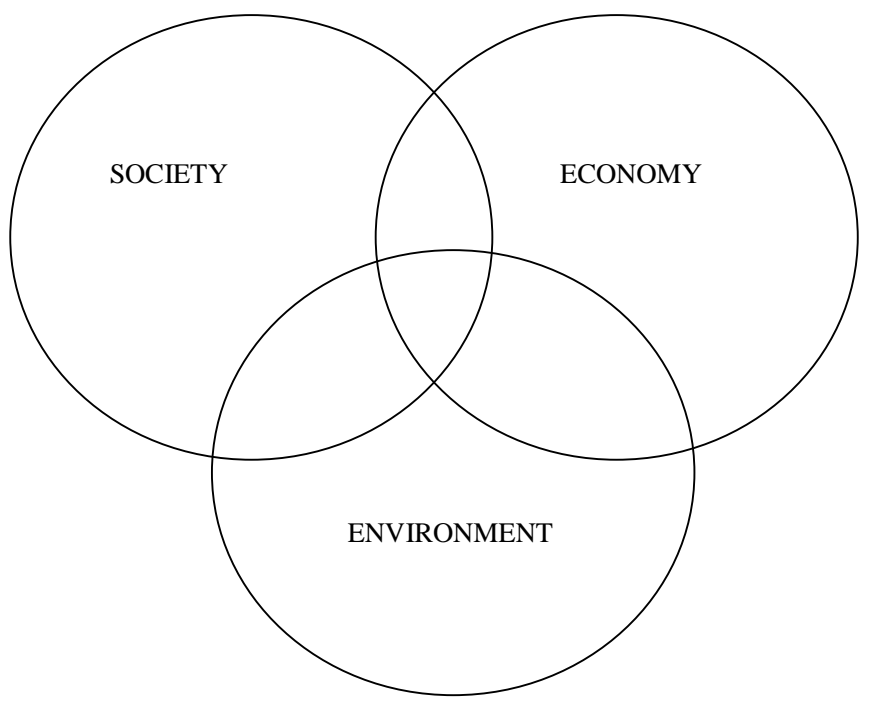

Source: Jones, Comfort, Hillier, 2011, p. 259.

Therefore, sustainable development can be seen as a developmental process that links economic, environmental, and social aspects, establishing a circle among the three poles. This is an economically sustainable development that is socially just, and environmentally feasible. In other words, the main objectives of the company may still be to reduce risk and increase returns to shareholders. It follows that companies focus more on workers and less on profit. Thus defined, sustainable development does not apply to only one segment of the company; on the contrary, it should be multifunctional, i.e. all functions of the company should be included and contribute to the overall policy of social responsibility.

Thus viewed, the concept of sustainable development finds its theoretical and practical application in many segments of the economy. Due to the fact that it is in direct contact with consumers, and that it plays a key role in connecting producers and consumers and the community as a whole, the question of applying the concept of sustainable development in trade arises. In the following discussion, we will try to answer this question, first from a theoretical point of view, and then through research on the structure and content of the concept of sustainable development in the ten leading trading companies. 


\section{The Concept of Sustainable Development in Trade}

Requirements for preserving the unchanged natural conditions and environment are relatively recent. They arose when it was realized that rapid technological progress, which is undeniably a step further in relation to the previous one, has a negative side that threatens man and his environment. Requirements for the preservation of the environment are in the hands of the state institutions, and these requirements appear in the form of laws, standards and regulations harmonized at the national and international level, which production or trade companies must meet (Ćuzović, Ivanović, 2010, p. 345).

Environmental problems are challenging for the trade management, as they foreground activities aimed at achieving eco-satisfaction of consumers. Value for the consumers is not only reflected in functional and structural determinants of qualitative shaping of "package deals" (range), or the service quality. The consumer value of products and services included in the offer extends to the area of eco quality. This means that the consumer's value concept of "package deals" of the trading company means the unity of the quality of the range in terms of technical and technological determinants (defined by standard ISO 9000) and environmental determinants (defined by standard ISO 14000), along with the quality of service, as an additional marketing tool. In this view, ecology has become not only the norm to achieve the consumer value of the range of products in terms of ecological quality, but also the cultural pattern of behavior of environmentally educated citizens, entrepreneurs, and managers. Ecological rationality, as can be seen in recent times, has become an important instrument in the marketing strategy of the trading companies (Ćuzović, Sokolov-Mladenović, 2013, p. 33).

Application of the concept of sustainable development in trade, especially in retail, is relatively recent. Its application, in addition to environmental, includes the economic and social dimension, which we have already discussed. Many trading companies view this concept as a separate strategy for achieving business success (Lukić, 2012, p. 575).

Although the concept of sustainable development stands for an insufficiently explored determinant of competitive recognizability and business performance of trading companies, the literature has crystallized the view that this concept in the trade can be seen through the following attributes (Yudelson, 2010, p. 50): green retail buildings, green processes, green transportation, green product, green price, green technology, green logistics, employment, wages, better working conditions for employees, continuous improvement of employees' knowledge, innovation, development of brand of organic products, managing relationships with customers, reducing the cost of the environment (water, air, energy), etc. Modern technologies, especially those that carry the epithet green, support the efficient application of the concept of sustainable 
development in trade, with all of these attributes. Finally, it has a positive impact on the economic, environmental, and social performance of trading companies, as shown by the financial statements of the leading trading companies which are the subject of research (Deloitte, 2014).

It can be seen from the above that the concept of sustainable development in trade is a function of several variables, many of which constitute "intangible" determinant of business success of companies. On the other hand, this opens the question of how to measure the contribution of these "attributes" of the concept of sustainable development. It is a kind of marketing mix of economically measurable performance, "green-ecological" and "ethical" that cannot be precisely measured.

This does not exhaust the list of unknowns that the research on the development and application of the concept of sustainable development in trade imposes. For example, this opens the question of measuring the efficiency of implementation of the concept of sustainable development in trade. We sought the answer to this question by relying on the model of factorial conditioning of the implementation of the concept of sustainable development in trade (Figure 2).

Figure 2: Model of factorial conditioning of the implementation of the concept of sustainable development in trade

\begin{tabular}{|c|c|c|}
\hline \multicolumn{3}{|c|}{ Sustainable retailing } \\
\hline $\begin{array}{l}\text { Environment } \\
\text { - Green buildings } \\
\text { - Renewable energy } \\
\text { - Stakeholder education } \\
\text { - Green products and partnerships } \\
\text { - Recycling and waste reduction } \\
\text { - Consumer behavior } \\
\text { - Supply chain management and } \\
\text { transportation }\end{array}$ & $\begin{array}{l}\text { Society } \\
\text { - Human rights } \\
\text { - Diversity } \\
\text { - Fair trade } \\
\text { - Fair consumption } \\
\text { - Safety and security } \\
\text { - Philanthropy }\end{array}$ & $\begin{array}{l}\text { Economy } \\
\text { - Value of shares } \\
\text { - Financial objectives } \\
\text { - Corporate governance } \\
\text { - Economic performance }\end{array}$ \\
\hline $\begin{array}{l}\text { Accountability and } \\
\text { transparency }\end{array}$ & $\begin{array}{l}\text { Regulatory compliance } \\
\text { Sustainability reporting }\end{array}$ & $\begin{array}{l}\text { Third party auditing } \\
\text { Measurement }\end{array}$ \\
\hline \multirow{2}{*}{ Leadership } & Visible leadership & Program management \\
\hline & Business case & Integration \\
\hline
\end{tabular}

Source: Gleason, D. (2010) Sustainable Retail Consortium - Introduction to Environmental Sustainability, The National Retail Federation, Available at: http://dkganalytics.com (Accessed on: 13 May 2014) 
Initiatives of numerous trade associations show that the concept of sustainable development is an essential element of the business of trading companies. For example, in 2007, Retail Industry Leader Association (RILA), which is a trade association of the world's largest and most innovative trading companies and has over 200 members, launched the so-called Sustainability Initiative. This initiative has been transformed into the annual sustainability reports published by RILA, whose aim is to mark out the key elements of the application of the concept of sustainable development in trading companies, with a comprehensive analysis of the key points of success, as well as the problems in the implementation of this concept in the companies that are members of the association RILA (Retail Sustainability Report, 2013, pp. 4-5).

\section{Methodology of Research}

In accordance with the defined goal of research on the possibilities of implementation of the concept of sustainable development in trade, the paper, as we have already noted, tests two hypotheses:

H1: Trading companies operate in accordance with the principles of sustainable development.

H2: Application of the concept of sustainable development has a positive impact on the business success of trading companies.

These hypotheses will be tested on the basis of a database of 250 major trading companies in the world, published annually, in the form of a Report, by the consulting firm Deloitte Touche (www.deloittetouche.com), as well as on the basis of the annual Sustainability Reports of the ten largest trading companies in the world.

Table 2: Business performance indicators of 250 largest trading companies in 2012

\begin{tabular}{||l|c||}
\hline \multicolumn{1}{|c|}{ Business performance } & Value \\
\hline Aggregate sales volume & 429 billion dollars \\
\hline Average sales volume & 17.15 billion dollars \\
\hline $\begin{array}{l}\text { Minimum sales volume needed for the company } \\
\text { to be included in the list of 250 major companies }\end{array}$ & 3.8 billion dollars \\
\hline $\begin{array}{l}\text { Increase in the sales volume in 2012 in relation } \\
\text { to 2011 }\end{array}$ & $4.9 \%$ \\
\hline $\begin{array}{l}\text { Annual growth rate of sales volume in the } \\
\text { period 2007-2012 }\end{array}$ & $4.6 \%$ \\
\hline Net profit margin (in 2011 it amounted to 3.0\%) & $3.1 \%$ \\
\hline Return on assets (in 2011 it amounted to 4.9\%) & $5.0 \%$ \\
\hline $\begin{array}{l}\text { Sales volume on the international market (in } \\
\text { 2011 it amounted to 23.8\%) }\end{array}$ & $24.3 \%$ \\
\hline
\end{tabular}

Source: Delloite Touche, 2014 
In accordance with the methodology of scientific research, the development of the topic started from the consideration of the business performance of the trade sector, i.e. 250 leading trading companies on the global market. The relevant source for economic objectification of business performance of international trading companies was the report of the consulting firm Deloitte. The business performance of the 250 largest trading companies is displayed numerically ("aggregately") in Table 2.

The table shows that the largest trading companies experienced relatively steady growth in the years of the crisis, considering the sales volume, net profit margin, return on assets, turnover ratio, and the sales volume outside the national market. This points to the conclusion that the trade sector in the global economic crisis is characterized by a relatively rapid response to changes in the environment and "consolidation" of business capacity (Sands \& Ferraro, 2010, p. 569).

The business performance of the ten largest trading companies, which have been the subject of analysis, can be seen in Table 3 .

Tabela br. 3: Deset najvećih trgovinskih kompanija na svetu i njihove poslovne performanse 2012. godine

\begin{tabular}{|c|c|c|c|c|c|c|c|c|}
\hline No. & Company & Country & $\begin{array}{l}\text { Sales } \\
\text { volume in } \\
\text { mil. \$ }\end{array}$ & 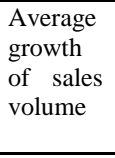 & $\begin{array}{l}\text { Net } \\
\text { profit } \\
\text { margin }\end{array}$ & $\begin{array}{l}\text { Return } \\
\text { on } \\
\text { assets }\end{array}$ & $\begin{array}{l}\text { Number of } \\
\text { countries } \\
\text { in which } \\
\text { company } \\
\text { operates }\end{array}$ & $\begin{array}{l}\text { Sales volume } \\
\text { on the } \\
\text { international } \\
\text { market }\end{array}$ \\
\hline 1. & Wal-Mart & USA & 469.162 & $5 \%$ & $3,8 \%$ & $8,7 \%$ & 28 & $29,1 \%$ \\
\hline 2. & Tesco & $\begin{array}{l}\text { Great } \\
\text { Britain }\end{array}$ & 101.269 & $0,5 \%$ & $0,2 \%$ & $0,2 \%$ & 13 & $33,5 \%$ \\
\hline 3. & Costco & USA & 99.137 & $11,5 \%$ & $1,8 \%$ & $6,5 \%$ & 9 & $27,6 \%$ \\
\hline 4. & Carrefour & France & 98.757 & $-5,5 \%$ & $1,7 \%$ & $2,9 \%$ & 31 & $54 \%$ \\
\hline 5. & Kroger & USA & 96.751 & $7,1 \%$ & $1,6 \%$ & $6,1 \%$ & 1 & $0 \%$ \\
\hline 6. & Schwarz & Germany & 87.236 & $6,6 \%$ & - & - & 26 & $57,7 \%$ \\
\hline 7. & Metro & Germany & 85.832 & $0,1 \%$ & $0,2 \%$ & $0,3 \%$ & 32 & $61,6 \%$ \\
\hline 8. & Home Depot & USA & 74.754 & $6,2 \%$ & $6,1 \%$ & $11 \%$ & 5 & $11,2 \%$ \\
\hline 9. & Aldi & Germany & 73.035 & $7,5 \%$ & - & - & 17 & $59,2 \%$ \\
\hline 10. & Target & USA & 71.960 & $5,1 \%$ & $4,1 \%$ & $6,2 \%$ & 1 & $0 \%$ \\
\hline \multicolumn{3}{|c|}{ Top 10} & 1.257 .892 & $4,2 \%$ & $2,8 \%$ & $5,8 \%$ & 16,3 & $32,3 \%$ \\
\hline \multicolumn{3}{|c|}{ Top 250} & 4.287 .587 & $4,9 \%$ & $3,1 \%$ & $5 \%$ & 10 & $24,3 \%$ \\
\hline \multicolumn{9}{|c|}{$\begin{array}{ll}\text { The share of sales volume of Top } 10 \text { companies in sales volume of Top } 250 \text { companies } & 29,3 \% \\
\end{array}$} \\
\hline
\end{tabular}

Source: Delloite Touche, 2014

We analyzed the extent to which these companies apply the concept of sustainable development on the basis of their regular annual sustainability reports (sustainable development). The results of this analysis can be seen in Tables 4 and 5. 
Table 4: Application of the concept of sustainable development in Top 10 trading companies

\begin{tabular}{|l|l|c|c|c||}
\hline \multirow{2}{*}{ No. Company } & \multicolumn{3}{|c|}{ Sustainable development } \\
\cline { 3 - 5 } & & $\begin{array}{c}\text { Environmental } \\
\text { dimension }\end{array}$ & Social dimension & $\begin{array}{c}\text { Economic } \\
\text { dimension }\end{array}$ \\
\hline 1. & Wal-Mart & $\sqrt{ }$ & $\sqrt{ }$ & $\sqrt{ }$ \\
\hline 2. & Tesco & $\sqrt{ }$ & $\sqrt{ }$ & $\sqrt{ }$ \\
\hline 3. & Costco & $\sqrt{ }$ & $\sqrt{ }$ & $\sqrt{ }$ \\
\hline 4. & Carrefour & $\sqrt{ }$ & $\sqrt{ }$ & $\sqrt{ }$ \\
\hline 5. & Kroger & $\sqrt{ }$ & $\sqrt{ }$ & $\sqrt{ }$ \\
\hline 6. & Schwarz & $\sqrt{ }$ & $\sqrt{ }$ & $\sqrt{ }$ \\
\hline 7. & Metro & $\sqrt{ }$ & $\sqrt{ }$ & $\sqrt{ }$ \\
\hline 8. & Home Depot & $\sqrt{ }$ & $\sqrt{ }$ & $\sqrt{ }$ \\
\hline 9. & Aldi & $\sqrt{ }$ & $\sqrt{ }$ & ( \\
\hline 10. & Target & Aung
\end{tabular}

Source: Authors' analysis based on Wal-Mart 2013 Global Responsibility Report, Tesco and Society Report 2013, Costco Corporate Sustainability Report 2013, Carrefour 2013 Annual Activity and Sustainability Report, Kroger 2013 Sustainability Report 2013, Corporate Responsibility Lidl 2013, Metro Group Sustainability Report 2013, Home Depot Sustainability Report 2013, ALDI Corporate Responsibility Policy 2013, Target Corporate Responsibility Report 2013.

Research results shown in Tables 4 and 5 represent an important, but not sufficient element in the search for answers to the question: to what extent does the implementation of the concept of sustainable development influence the competitive recognizability and business performance of analyzed trading companies. On the other hand, the relevance of our research would be compromised if it lacked research "niche" that should give an answer to the question: what are the components of sustainable development and to what extent do they (not) contribute to the competitive recognizability and business performance of ten largest trading companies. The principle of research curiosity reminds us that the hypotheses that we set remain a dead letter if we do not confirm or deny them. Guided by this principle of scientific research, it is our obligation to rely on the available theoretical and empirical material and explore the extent to which the implementation of the concept of sustainable development in the marketing strategy of the analyzed trading companies affects their business performance.

Before answering this question, academic etiquette and methodology of scientific research remind us that we are not always able to collect all data, based on direct contact (interviews, questionnaires) on the "polygon" in practice, and thus structuring the marketing information system that would serve as a platform for the economic objectification of the research problem and making relevant decisions. Nevertheless, the modern theory and practice took care to find adequate access to the collection, processing, and economic objectification of certain phenomena. So it is in this research. As we have already pointed out, we sought the answer to the question of the extent to which individual components of the concept of sustainable development affect the competitive recognizability and business performance of the ten largest trading companies, relying on the companies' annual reports on sustainable development. 
Table 5: Dimensions of sustainable development in Top 10 trading companies

\begin{tabular}{|c|c|c|c|c|c|c|c|c|c|c|}
\hline $\begin{array}{l}\text { Dimensions of } \\
\text { sustainable } \\
\text { development }\end{array}$ & $\begin{array}{l}\text { Wal- } \\
\text { Mart }\end{array}$ & Tesco & Costco & Carrefour & Kroger & Schwarz & Metro & $\begin{array}{l}\text { Home } \\
\text { Depot }\end{array}$ & Aldi & Target \\
\hline \multicolumn{11}{|c|}{ Environmental dimension } \\
\hline $\begin{array}{l}\text { Climate change } \\
\text { and carbon } \\
\text { emissions }\end{array}$ & $\sqrt{ }$ & $\sqrt{ }$ & $\sqrt{ }$ & $\sqrt{ }$ & $\sqrt{ }$ & $\sqrt{ }$ & $\sqrt{ }$ & $\mathrm{x}$ & $\sqrt{ }$ & $\sqrt{ }$ \\
\hline $\begin{array}{l}\text { Energy } \\
\text { consumption }\end{array}$ & $\sqrt{ }$ & $\sqrt{ }$ & $\sqrt{ }$ & $\sqrt{ }$ & $\sqrt{ }$ & $\sqrt{ }$ & $\sqrt{ }$ & $\mathrm{x}$ & $\sqrt{ }$ & $\sqrt{ }$ \\
\hline $\begin{array}{l}\text { Water } \\
\text { management }\end{array}$ & $\sqrt{ }$ & $\sqrt{ }$ & $\sqrt{ }$ & $\sqrt{ }$ & $\mathrm{x}$ & $\mathrm{x}$ & $\mathrm{x}$ & $\mathrm{x}$ & $\mathrm{x}$ & $\sqrt{ }$ \\
\hline $\begin{array}{l}\text { Waste } \\
\text { management }\end{array}$ & $\sqrt{ }$ & $\sqrt{ }$ & $\mathrm{x}$ & $\sqrt{ }$ & $\sqrt{ }$ & $\sqrt{ }$ & $\sqrt{ }$ & $\sqrt{ }$ & $\sqrt{ }$ & $\sqrt{ }$ \\
\hline Logistics & $\sqrt{ }$ & $\sqrt{ }$ & $\mathrm{x}$ & $\sqrt{ }$ & $\mathrm{x}$ & $\sqrt{ }$ & $\sqrt{ }$ & $\mathrm{x}$ & $\mathrm{X}$ & $\sqrt{ }$ \\
\hline $\begin{array}{l}\text { Preservation } \\
\text { of natural } \\
\text { resources }\end{array}$ & $\sqrt{ }$ & $\sqrt{ }$ & $\mathrm{x}$ & $\sqrt{ }$ & $\sqrt{ }$ & $\mathrm{x}$ & $\mathrm{x}$ & $\sqrt{ }$ & $\sqrt{ }$ & $\sqrt{ }$ \\
\hline $\begin{array}{l}\text { Environmental } \\
\text { products }\end{array}$ & $\sqrt{ }$ & $\sqrt{ }$ & $\sqrt{ }$ & $\sqrt{ }$ & $\sqrt{ }$ & $\sqrt{ }$ & $\sqrt{ }$ & $\sqrt{ }$ & $\sqrt{ }$ & $\sqrt{ }$ \\
\hline $\begin{array}{l}\text { Land and } \\
\text { property fund }\end{array}$ & $\sqrt{ }$ & $\sqrt{ }$ & $\sqrt{ }$ & $\sqrt{ }$ & $\sqrt{ }$ & $\mathrm{x}$ & $\mathrm{x}$ & $\mathrm{x}$ & $\mathrm{x}$ & $\sqrt{ }$ \\
\hline \multicolumn{11}{|c|}{ Social dimension } \\
\hline \begin{tabular}{l|} 
Responsible \\
supply
\end{tabular} & $\sqrt{ }$ & $\sqrt{ }$ & $\mathrm{x}$ & $\sqrt{ }$ & $\sqrt{ }$ & $\sqrt{ }$ & $\mathrm{x}$ & $\mathrm{x}$ & $\sqrt{ }$ & $\sqrt{ }$ \\
\hline Food safety & $\mathrm{x}$ & $\sqrt{ }$ & $\mathrm{x}$ & $\sqrt{ }$ & $\sqrt{ }$ & $\sqrt{ }$ & $\mathrm{x}$ & $\mathrm{x}$ & $\sqrt{ }$ & $\sqrt{ }$ \\
\hline $\begin{array}{l}\text { Conditions of } \\
\text { work with the } \\
\text { suppliers }\end{array}$ & $\sqrt{ }$ & $\sqrt{ }$ & $\sqrt{ }$ & $\sqrt{ }$ & $\sqrt{ }$ & $\mathrm{x}$ & $\sqrt{ }$ & $\mathrm{x}$ & $\sqrt{ }$ & $\sqrt{ }$ \\
\hline $\begin{array}{l}\text { Different and } \\
\text { equal } \\
\text { opportunities }\end{array}$ & $\sqrt{ }$ & $\sqrt{ }$ & $\sqrt{ }$ & $\sqrt{ }$ & $\sqrt{ }$ & $\sqrt{ }$ & $\sqrt{ }$ & $\mathrm{x}$ & $\mathrm{x}$ & $\sqrt{ }$ \\
\hline $\begin{array}{l}\text { Training and } \\
\text { development }\end{array}$ & $\sqrt{ }$ & $\sqrt{ }$ & $\sqrt{ }$ & $\sqrt{ }$ & $\sqrt{ }$ & $\mathrm{x}$ & $\sqrt{ }$ & $\mathrm{x}$ & $\sqrt{ }$ & $\sqrt{ }$ \\
\hline $\begin{array}{l}\text { Health and } \\
\text { safety }\end{array}$ & $\sqrt{ }$ & $\sqrt{ }$ & $\sqrt{ }$ & $\sqrt{ }$ & $\sqrt{ }$ & $\sqrt{ }$ & $\mathrm{x}$ & $\sqrt{ }$ & $\sqrt{ }$ & $\sqrt{ }$ \\
\hline $\begin{array}{l}\text { Relations with } \\
\text { the local } \\
\text { communities }\end{array}$ & $\sqrt{ }$ & $\sqrt{ }$ & $\sqrt{ }$ & $\sqrt{ }$ & $\sqrt{ }$ & $\mathrm{x}$ & $\mathrm{x}$ & $\sqrt{ }$ & $\mathrm{x}$ & $\sqrt{ }$ \\
\hline $\begin{array}{l}\text { Charitable } \\
\text { contributions }\end{array}$ & $\sqrt{ }$ & $\sqrt{ }$ & $\sqrt{ }$ & $\sqrt{ }$ & $\sqrt{ }$ & $\sqrt{ }$ & $\sqrt{ }$ & $\sqrt{ }$ & $\sqrt{ }$ & $\sqrt{ }$ \\
\hline \multicolumn{11}{|c|}{ Economic dimension } \\
\hline $\begin{array}{l}\text { Creating } \\
\text { employment }\end{array}$ & $\sqrt{ }$ & $\sqrt{ }$ & $\sqrt{ }$ & $\sqrt{ }$ & $\mathrm{x}$ & $\sqrt{ }$ & $\mathrm{x}$ & $\mathrm{x}$ & $\sqrt{ }$ & $\sqrt{ }$ \\
\hline $\begin{array}{l}\text { Customer } \\
\text { value }\end{array}$ & $\sqrt{ }$ & $\sqrt{ }$ & $\mathrm{x}$ & $\sqrt{ }$ & $\mathrm{x}$ & $\mathrm{x}$ & $\mathrm{x}$ & $\mathrm{x}$ & $\mathrm{x}$ & $\sqrt{ }$ \\
\hline $\begin{array}{l}\text { Relations with } \\
\text { the suppliers }\end{array}$ & $\sqrt{ }$ & $\sqrt{ }$ & $\mathrm{x}$ & $\sqrt{ }$ & $\mathrm{x}$ & $\mathrm{x}$ & $\mathrm{x}$ & $\sqrt{ }$ & $\sqrt{ }$ & $\sqrt{ }$ \\
\hline $\begin{array}{l}\text { Creating value } \\
\text { for stakeholders }\end{array}$ & $\mathrm{x}$ & $\sqrt{ }$ & $\sqrt{ }$ & $\sqrt{ }$ & $\mathrm{x}$ & $\mathrm{x}$ & $\mathrm{x}$ & $\mathrm{x}$ & $\mathrm{x}$ & $\sqrt{ }$ \\
\hline $\begin{array}{l}\text { Corporate } \\
\text { governance }\end{array}$ & $\mathrm{X}$ & $\sqrt{ }$ & $\mathrm{X}$ & $\sqrt{ }$ & $\sqrt{ }$ & $\mathrm{X}$ & $\mathrm{x}$ & $\sqrt{ }$ & $\mathrm{x}$ & $\sqrt{ }$ \\
\hline
\end{tabular}

Source: Authors' analysis based on Wal-Mart 2013 Global Responsibility Report, Tesco and Society Report 2013, Costco Corporate Sustainability Report 2013, Carrefour 2013 Annual Activity and Sustainability Report, Kroger 2013 Sustainability Report 2013, Corporate Responsibility Lidl 2013, Metro Group Sustainability Report 2013, Home Depot Sustainability Report 2013, ALDI Corporate Responsibility Policy 2013, Target Corporate Responsibility Report 2013. 


\section{Research Results and Discussion}

Research results shown in Tables 4 and 5 indicate that marketing management of trading companies bases their vision, mission, and business strategy on the concept of sustainable development. Analytically observed, environmental, social, and economic determinants of sustainable development come to the fore. In addition, the results of the research show that all three dimensions of sustainable development do not apply with the same intensity, or do not apply in terms of all elements in the analyzed companies.

The environmental dimension of sustainable development, according to the data from Table 4, is present in all companies. It is analyzed through the presence of several elements: climate change and carbon emissions, energy consumption, water management, waste management, logistics, preservation of natural resources, environmental products, and land and property fund. As shown in Table 5, all these elements are present in the companies Wal-Mart, Carrefour, Tesco, and Target, while other companies lack some of the elements. For example, the company Wal-Mart, the world leader, emphasizes environmental responsibility as a distinctive element of their successful business (Wal-Mart 2013 Global Responsibility Report). In support of this fact, there is information that by the end of 2012 this company had 280 projects related to renewable energy on the markets where it operates. As a result, the company was able to provide $21 \%$ of the demand for electricity from renewable sources. In addition, during the period from 2005 to 2012, the company managed to decrease emissions of harmful gases by $20 \%$. This does not exhaust the list of innovations with which this company enhances the environmental dimension of sustainable development. When it comes to waste management, Wal-Mart managed to achieve a record in 2012, by recycling $80 \%$ of the waste from its retail stores and distribution centers, and reducing the use of plastic bags by $38.1 \%$ across all retail stores throughout the world. An important segment of the environmental dimension of this company are environmental products in which Wal-Mart in 2012 invested 300 million dollars, in collaboration with its suppliers.

The British company Tesco, as the second retail chain in the world, also applies all elements of the environmental dimension of the concept of sustainable development (Tesco and Society Report 2013). Based on the analysis of their Sustainability Report, particular emphasis needs to be placed on their activities in the field of greenhouse gas emissions, given that in the period from 2006 to 2012 they reduced the emissions of harmful gases by $25 \%$. Waste and water management is another essential element of their business strategy.

Analysis of the Sustainability Report of the company Carrefour (Carrefour 2013 Annual Activity and Sustainability Report) shows that it is a responsible company. This is supported by the fact that they offer more than 2,300 
environmental products in their stores, which they developed through marketing partnerships with the suppliers. Since 1996, the company has applied a preventive approach in the process of creating the range of genetically modified products. Moreover, what makes this company so recognizable is the cooperation with more than 6,000 farmers in the development of environmental products.

The application of all elements of the environmental dimension of sustainability is also present in the company Target (Target Corporate Responsibility Report 2013). Special emphasis needs to be placed on the company's activities aimed at reducing the use of plastic bags, reducing the emission of harmful waste, and increasing efficiency of electricity by $50 \%$ in the period from 2007 to 2012 .

Social dimension of sustainable development, based on data from Table 4 , is present in all analyzed companies. In this regard, its presence is seen through several elements: responsible supply, food safety, conditions of work with the suppliers, different and equal opportunities, training and development, health and safety, relationships with local communities and charitable contributions. What is particularly evident in Table 5, based on the analysis of the Sustainability Report of these companies, is that all these elements are not equally present in all companies. Their complete application is recorded in the companies Tesco, Carrefour, Kroger, and Target, while the other companies lack some of the elements. For example, the company Tesco, as the second largest trading company in the world, applies all elements of the social dimension of sustainable development. One of these elements, through which the company differentiates itself from its competitors, is the offer of safe and healthy products. An example of this is the fact that in 1984 the company opened the first Tesco supermarket, in which $30 \%$ of the product range consisted of environmentally healthy products. In addition, in its Sustainability Report (Tesco and Society Report 2013), the company highlights the strong and long-term relationships with its suppliers and local communities. The evidence of this is seen in the company's total donation in 2012 of 78 million euros, which represents a $4 \%$ allocation of pre-tax profit for the charity.

French retail chain, Carrefour, also applies all elements of the social dimension of sustainable development (Carrefour 2013 Annual Activity and Sustainability Report). The fact that supports this statement is that in 2012, the company increased sales of organic and environmental products by $9.3 \%$, compared to 2011 . In its product range, the company offers more than 1,700 socalled fair trade products in retail stores around the world, and over 600 product lines with the label eco, natural, and bio.

The implementation of the social dimension of sustainable development in the American company Kroger is illustrated by statistical data (Kroger 2013 Sustainability Report 2013). In 2012, this company donated 200 million meals 
to the most vulnerable groups of people throughout the United States, given that the company operates only on the American market. Another illustrative fact is that in 2012 the company supported more than 30,000 schools and local organizations, donated 5.9 million dollars to improve the health of women and the prevention of cancer, and 3.3 million dollars to the most vulnerable families. Therefore, what distinguishes Kroger in relation to other companies is the intense policy of giving donations to local and social community.

The American company Target applies all elements of the social dimension of sustainable development, and in its Sustainability Report (Target Corporate Responsibility Report 2013) highlights strong cooperation with the local community and responsible supply. It is illustrative that the company cooperates with over 3,500 manufacturers in more than 50 countries, while insisting on respecting human and children's rights in the production of products, i.e. in the production of the so-called fair trade products. In order to protect itself from eco "unconscientious" suppliers, the company adopted internal standards for the selection of suppliers, in order to fully comply with the principle of responsible supply. For the purpose of structuring the eco "package" deals in respect of safe and healthy products, the company carries out rigorous control of more than 132,000 products that make up the structure of its range.

The economic dimension of sustainable development, based on data from Table 4, is present in all analyzed companies. In this regard, its presence can be seen through the following elements: creating employment, customer value, relations with suppliers, creating value for stakeholders, and corporate governance. All these elements (Table 5) are fully present in the companies Tesco, Carrefour, and Target, while the other companies lack some of these elements. Tesco, as the second largest trading company in the world, in its Sustainability Report (Tesco and Society Report 2013) states that the economic dimension of sustainable development places emphasis on solving the problem of unemployment. Thus, this company employs over 500,000 people around the world, trying to make the equal participation of men and women. Good image of the company is seen in its cooperation with the suppliers, as well as corporate governance, as an important element of the economic dimension of sustainable development.

The French trading company, Carrefour, implements the economic dimension of sustainable development through the permanent policy of creating new jobs and increasing the participation of women in the management. Thus, this company employs over 400,000 people worldwide, and in the period from 2006 to 2012 it increased participation of women in its management team by 3.4\% (Carrefour 2013 Annual Activity and Sustainability Report).

In respect of the economic dimension of sustainable development, the American trading company, Target, places significant emphasis on its 
employees, their education, and their health. As proof of this, there are permanent training programs, and preventive health care activities of staff (Target Corporate Responsibility Report 2013).

Wrapping up the discussion on the topic of environmental, economic, and social determinants of sustainable development in trade, the methodology of scientific research obliges us, relying on the results of research, to confirm or reject the hypothesis that we set in the research.

Previous analysis of the environmental, social, and economic dimensions of sustainable development indicates their presence in the analyzed companies, as seen by different elements. Therefore, the first hypothesis about the operations of trading companies in accordance with the principles of sustainable development has been confirmed. In addition, as we have already pointed out, we looked at the top ten trading companies on the Top 250 list, as seen by sales volume in 2012.

On the other hand, judging by the presence of elements of environmental, social, and economic dimensions of sustainable development, the research has shown different intensity of their application. The companies Tesco and Carrefour apply all elements of environmental, social, and economic dimensions of sustainable development. It should be noted that Tesco is the second, whereas Carrefour is the fourth retail chain in the world, as seen by sales volume. It is an undisputed fact that these positions are partly the result of the application of the concept of sustainable development, which is specifically mentioned in their sustainability reports. Therefore, the second hypothesis examined in this research has been confirmed, stating that the concept of sustainable development has a positive impact on competitiveness recognizability and business performance of trading companies. In addition, this hypothesis is confirmed by the presence of the concept of sustainable development in other trading companies that are on the list of the ten largest trading companies in the world, as seen by sales volume in 2012 .

\section{Conclusion}

The concept of sustainable development has become an imperative of modern business conditions. As the problems of protection and conservation of living and working environment are becoming more pronounced, this concept is gaining in importance. Trading companies, as the intermediaries between producers and consumers, have a responsible role in the implementation and promotion of the concept of sustainable development. In that regard, contemporary theories and progressive practice in the field of trade management have crystallized different approaches in implementing the concept of sustainable development. The problem of its clear definition becomes more pronounced with the advent of different definitions, so this paper 
shows that there are as many definitions of the concept of sustainable development as the authors who have dealt with this issue. What is common to all these definitions and attitudes is that the concept of sustainable development includes three dimensions: environmental, social, and economic. We have tried to explore whether and to what extent this concept is present in trade and trade management, following the example of the ten largest trading companies in the world, as seen by sales volume, based on their annual sustainability reports. The research results have shown that in these companies all three dimensions of sustainable development are present, which has allowed us to prove the first hypothesis, placing emphasis on the operations of trading companies in accordance with the principles of sustainable development. Furthermore, the research focused on more detailed insight into the dimensions of sustainable development. Each of these dimensions can be seen through different elements, which are more or less present in trading companies. This analysis and the results of the research suggest that only the companies Carrefour and Tesco record all the elements of environmental, social, and economic dimensions of sustainable development. Given that these companies are at the top of the list of the most successful trading companies in the world, we have confirmed the second hypothesis, on the basis of which the concept of sustainable development has a positive impact on the business success. It is proven by the presence of these elements in other companies that are on the list of the ten most successful trading companies in the world. In proving the hypotheses, we analyzed the practice of the ten largest trading companies in the world, as seen by sales volume in 2012 .

\section{References}

ALDI Corporate Responsibility Policy 2013, Available at: www.aldi-corporateresponsibility-policy.me-digital.co.uk/aldi_PDFs.pdf (Accessed on 17 May 2014)

Callicott, J.B. and Mumford, K. (1997) Ecological sustainability as a conservation concept“", Biological Conservation, 11 (1): 32-40.

Carrefour 2013 Annual Activity and Sustainability Report, Available at: www.carrefour.com/site/default/files/RADDEN2013.pdf (Accessed on 17 May 2014)

Constanza, R. and Pattern, B.C. (1995) "Defining and predicting sustainability“, Ecological Economics, 15 (3): 192-196.

Corporate Responsibility Lidl 2013, Available at: www.lidl.co.uk (Accessed on 17.05.2014)

Costco Corporate Sustainability Report 2013, Available at: http://corporateir.net/External.File (Accessed on 14 May 2014)

Ćuzović, S., Ivanović, P. (2010) Inovacije u trgovinskom menadžmentu, Niš: Ekonomski fakultet. 
Ćuzović, S., Sokolov-Mladenović, S. (2013) "Trade in Terms of Ecological Economics", The volume Challenges for the trade of Central and Southeast Europe, International Business \& Management, United Kingdom: Emerald, 29-37.

Dauncey, G. (2009) "Towards sustainability", Available at: www.towardssustainability.co.uk/infodir/susquote.html (Accessed on 10 May 2014)

Deloitte (2014) Global Power of Retailing 2014, Available at: www.deloittetouche/consumerbusiness (Accessed on 13 May 2014)

Ehrenfeld, J.R. (2005) "The roots of sustainability“, MIT Sloan Management Review, 46 (2): 23-25.

Fuchs, D. and Lorek, S. (2004) "Sustainable consumption", Available at: http://web205.vbox01.inode.at/Data/seri/publications/documents/SERI\%20Backgrou nd\%20Paper\%204.pdf (Accessed on 11 May 2014)

Gleason, D. (2010) Sustainable Retail Consortium - Introduction to Environmental Sustainability, the National Retail Federation, Available at: http://dkganalytics.com (Accessed on 13 May 2014)

Home Depot Sustainability Report 2013, Available at: https://corporate.homedepot.com/ CorporateResponsibility/Environment/Documents/Sustainability_Brochure_pages.pd $\mathrm{f}$ (Accessed on 17 May 2014)

Jones, P., Comfort, D., Hillier, D. (2011) "Sustainability in the global shop window", International Journal of Retail \& Distribution Management, 39 (4): 256-271.

Kroger 2013 Sustainability Report 2013, Available at: http://sustainability.kroger.com/pdf/ kroger-2013-CSR.pdf (Accessed on 17 May 2014)

Lozano, R. (2008) "Envisioning sustainability three-dimensionally“, Journal of Cleaner Production, 16(17): 1838-1846.

Lukić, R. (2012) "Sustainable Development of Retail in Serbia“, Review of International Comparative Management, 13(4): 574-585.

Metro Group Sustainability Report 2013, Available at: www.metrogroup.de/internet/site/ metrogroup/get/documents/metrogroup_international/corpsite/80_globall/publication s/SR2013-en.pdf (Accessed on 17 May 2014)

Parris, T.M. and Kates, R.W. (2003) "Characterizing and measuring sustainable development", Annual Review of Environment and Resources, 28 (1): 559-586.

Retail Sustainability Report (2013) Retail Industry Leader Association, Available at http://www.rila.org/sustainability/sustreport2013/sustainability-report-landingpage/Pages/default.aspx (Accessed on 13 May 2014)

Sands, S., \& Ferraro, C. (2010) "Retailers' strategic responses to economic downturn: insights from down under“, International Journal of Retail \& Distribution Management, 38 (8), 567-575.

Sutton, P. (2004) "A perspective on environmental sustainability“, Available at: www.ces.vic.gov.au (Accessed on 10 May 2014)

Target Corporate Responsibility Report 2013, Available at: https://corporate.target.com/ _media/TargetCorp/csr/pdf/2013-corporate-responsibility-report.pdf (Accessed on 17 May 2014)

Tesco and Society Report 2013, Available at: www.igd.com/our-expertise/Sustainability/ CSR/3151/Tesco-CSR-reports (Accessed on 1 May 2014) 
United Nations Environment Programme Finance Initiative (1997), UNEP Statement by Financial Institutions on the Environment \& Sustainable Development, Available at: unepfi.org/fileadmin/statements/fi/fi_statement_en.pdf (Accessed on 12 May 2014)

United Nations General Assembly (2005) 2005 World Summit Outcome, Available at: www.who.int/hiv/universalaccess2010/worldsummit.pdf (Accessed on 12 May 2014)

Wal-Mart 2013 Global Responsibility Report, Available at: http://corporate.walmart.com/ global-responsibility/environment-sustanibility/global-responsibility-report (Accessed on 14 May 2014)

Williams, C.C. and Millington, A.C. (2004) "The diverse and contested meanings of sustainable development“", The Geographical Journal, 170 (2): 99-104.

World Commission on Environment and Development (1987) Our Common Future, New York: Oxford University Press.

www.deloittetouche (Accessed on 14 May 2014)

Yudelson, J. (2010) Sustainable Retail Development: New Success Strategies, New York: Springer.

\section{TRGOVINSKI MENADŽMENT U SAVLAĐIVANJU TAJNI ODRŽIVOG RAZVOJA}

Apstrakt: Trgovina, posebno maloprodaja, ima važnu ulogu $u$ povezivanju proizvođača, potrošača, ali i zaposlenih i društvene zajednice u celini. U razvijenim tržišnim privredama, trgovina preuzima lidersku poziciju u kanalima marketinga. Sa te pozicije, trgovina ima dobar uvid u promene koje se javljaju u proizvodnji, potrebama potrošača i zahtevima društva. Imajući u vidu ove promene trgovina ide u pravcu kreiranje konkurentske prednosti u skladu s načelima održivog razvoja, što otvara mogućnosti primene ovog koncepta u trgovini. Cilj ovog rada jeste da istraži mogućnosti implementacije koncepta održivog razvoja u trgovini i trgovinskom menadžmentu. Polazna hipoteza u radu jeste da trgovinske kompanije posluju u skladu sa načelima održivog razvoja. Testiranje hipoteze vršiće se iz tri ugla. Istraživanje ćemo započeti analizom koncepta održivog razvoja. Drugo, predmet posebne analize $u$ radu biće sadržaj koncepta održivog razvoja u trgovini i maloprodaji, kao i elementi od uticaja na održivost poslovanja trgovinskih kompanija. Pri tome, predmet analize biće prvih deset trgovinskih kompanija sa liste 250 najvećih trgovinskih kompanija na svetu i njihov sadržaj koncepta održivog razvoja. Imajući u vidu dobijene rezultate istraživanja koncepta održivog razvoja u ovim kompanijama, može se očekivati da će trgovina svoju poslovnu filozofiju bazirati na eko-marketingu uz prihvatanje eko-menadžmenta. To znači da će opstanak na tržištu osigurati one kompanije koje su u mogućnosti ponuditi proizvodi koji ne zagađuju okolinu i koji nose oznaku „eko“, „bio“ ili „prirodno“. Treće, predmet istraživanja biće i instrumenti koje trgovinske kompanije koriste za ostvarivanje ciljeva održivog poslovanja. Svi ovi aspekti istraživanja koncipirani su na način da se realizuje postavljeni cilj i testira polazna hipoteza u radu.

Ključne reči: trgovina, održivi razvoj, trgovinske kompanije, ekološka, ekonomska, društvena dimenzija. 